Дмитро БОНДАРЕНКО, orcid.org/0000-0003-1608-1282 кандидат історичних наук, магістр соиіології, науковий співробітник Інституту стратегічних досліджень та прогнозів трансатлантичних процесів (Україна, Oдеса) dbond70@gmail.com

\title{
ВІД БРЕСТ-ЛИТОВСЬКОЇ ДО ВЕРСАЛЬСЬКОЇ СИСТЕМИ: МОНАРХІЧНА КОНТРРЕВОЛЮЦІЯ В ЦЕНТРАЛЬНІЙ ТА СХІДНІЙ ЄВРОПІ В 1918 - 1920 рp.
}

Монархічна контрреволючія в Центральній та Східній Європі виникла в деяких нових державах, щзо постали в результаті розпаду Російської та Австро-Угорської імперій, як відповідь на більшовицьку експансію. Чинники, щсо сприяли виникненню монархічної контрреволюиії, були: наявність державних монархічних традищій (наприклад, у Фінляндї̈ та Угорщцині) та наявність у нових державах харизматичних політичних та військових лідерів з монархічними поглядами. Деякі нові держави з республіканською формою правління були базами монархічної контрреволюиї в Росії (Украӥнська Держава, Всевелике Військо Донське, Естонська республіка). Згуртуванню монархічних сил колишньої Російської імперії сприяла німецькка дипломатія.

Поразка Німеччини у Першій Світовій війни призвела до відречення представників німецьких династій у Фінляндї та Литві. У Фінляндії та Угорщині монархічний лад було відновлено після перемоги над червоними, проте через тиск з боку Союзників королівства залишилися без королів. Якщо у Фінляндії контрреволючія перемогла самостійно, власними силами, то в Угорщині контрреволючію було занесено румунською інтервенцією через слабкість угорських білих.

Фактично, дипломатія Союзних держав, через підтримку російських білих республіканців, гаслом яких було «Єдина та неподільна Росія», призвела до поразки монархічної контрреволюиії у Росії та збереженню більшовицького режиму. Більше того, деякі нові держави (Українська Держава та Всевелике Військо Донське) втратили свою незалежність і зникли з мапи Свропи. За иими умовами нові регіональні потуги (Фінляндія та Румунія) стали флангами «Санітарного кордону».

Ключові слова: Брест-Литовська система, Версальська система, Тріанонська мирна угода, «Санітарний кордон», монархічна контрреволюиія, бази монархічної контрреволюиї, Фінляндія, Регент барон Карл Густав Маннергейм, Румунія, Король Фердинанд I, Угорщина, Регент Міклош Горті, Украӥнська Держава, Гетьман Павло Скоропадський, Всевелике Військо Донське, Отаман Петро Краснов.

Dmytro BONDARENKO, PhD (History), MA in Sociology, Research Fellow of Institute of Strategic Studies and Forecasting of Transatlantic Processes (Ukraine, Odessa)dbond70@gmail.com

\section{FROM BREST-LITOVSK TO VERSAILLES SYSTEM: MONARCHIST COUNTER- REVOLUTION IN CENTRAL AND EASTERN EUROPE IN 1918 - 1920}

The monarchical counter-revolution in Central and Eastern Europe arose also in some new states as a result of the collapse of the Russian and Austro-Hungarian empires and as a response to the Bolshevik expansion. The factors of the emergence of the monarchical counter-revolution were the following: the existence of state monarchical traditions (for example, in Finland and Hungary) and the presence of charismatic political and military leaders with monarchical views in the new states. Some new states with the republican form of rule became the bases of the monarchist counterrevolution in Russia (for instance, the Ukrainian State, the Great Don Host, Estonian Republic). The concentration of monarchical forces in the former Russian Empire was facilitated by German diplomacy.

Germany's defeat of in World War I led to the renunciation of the representatives of the German dynasties in Finland and Lithuania. In Finland and Hungary the monarchist system was restored after the victory over the Reds, however, because the pressure from the Allies made these kingdoms bereft left of their kings. Whereas in 
Finland the counter-revolution won the victory independently, due to its own forces, the counter-revolution in Hungary was entered by Romanian intervention because of the weakness of the Hungarian Whites.

In fact, the diplomacy of the Allies through the support of the Russian Republican Whites, whose slogan was "A unified and indivisible Russia», led to the defeat of the monarchist counter-revolution in Russia and the survival of the Bolshevik regime. Moreover, some new state (the Ukrainian State and the Great Don Host) lost their independence and disappeared from the map of Europe. Under these conditions, the new regional powers (Finland and Romania) became the flanks of "Cordon Sanitaire».

Keywords: Brest-Litovsk system, Versailles system, Peace Treaty of Trianon, "Cordon Sanitaire», monarchist counter-revolution, bases of monarchist counter-revolution, Finland, Regent baron Carl Gustav Mannerheim, Romania, King Ferdinand I, Hungary, Regent Mikloś Horthy, the Ukrainian State, Hetman Pavlo Skoropadskyi, the Great Don Host, Otaman Petro Krasnov.

Дмитрий БОНДАРЕНКО, кандидат исторических наук, магистр социологии, научный сотрудник Института стратегических исследований и прогнозов трансатлантических процессов (Украина, Oдесса)dbond70@gmail.com

\section{ОТ БРЕСТ-ЛИТОВСКОЙ ДО ВЕРСАЛЬСКОЙ СИСТЕМЫ: МОНАРХИЧЕСКАЯ КОНТРРЕВОЛЮЦИЯ В ЦЕНТРАЛЬНОЙ И ВОСТОЧНОЙ ЕВРОПЕ В 1918 - 1920 годах}

Монархическая контрреволюиия в Центральной и Восточной Европе возникла в некоторых новых государствах, которые возникли в результате распада Российской и Австро-Венгерской империй как ответ на большевистскую экспансию. Факторами, способствовавшими возникновению монархической контрреволючии, были: наличие государственных монархических традиций (например, в Финляндии и Венгрии) и наличие в новых государствах харизматических политических и военных лидеров с монархическими взглядами. Некоторые новые государства с республиканской формой правления были базами монархической контрреволючии в России (Украинская Держава, Всевеликое Войско Донское, Эстонская республика). Сплочению монархических сил бывщей Российской империи способствовала немецкая дипломатия.

Поражение Германии в Первой Мировой войны привела к отречению представителей немеиких династий в Финляндии и Литве. В Финляндии и Венгрии монархия была восстановлена после победы над красными, однако из-за давления со стороны Союзников королевства остались без королей. Если в Финляндии контрреволючия победила самостоятельно, собственными силами, то в Венгрии контрреволюиия была принесена румынской интервенцией по причине слабости венгерских бельх.

Фактически, дипломатия Союзных держав, через поддержку российских белых республиканцев, лозунгом которых был "Единая и неделимая Россия», привела к поражению монархической контрреволючии в России и сохранению большевистского режима. Более того, некоторые новые государства (Украинская Держсава и Всевеликое Войско Донское) потеряли свою независимость и исчезли с карты Европы. В этих условиях новые региональные державы (Финляндия и Румыния) стали флангами Санитарного кордона.

Ключевые слова: Брест-Литовская система, Версальская система, Трианонский мирный договор, «Санитарный кордон», монархическая контрреволюиия, базы монархической контрреволюиии, Финляндия, Регент барон Карл Густав Маннергейм, Румьлния, Король Фердинанд I, Венгрия, Регент Миклош Хорти, Украинская Держава, Гетман Павло Скоропадский, Всевеликое Войско Донское, Атаман Петр Краснов.

Постановка проблеми. Наприкінці Першої світової війни відбувся розпад останніх династичних держав Свропи: Російської та Австро-Угорської імперій. На територіях колишніх імперій виникли нові національні держави, деякі національні держави виправили свої кордони за гаслом збігання національних та державних кордонів, наприклад, Румунія завершила національне об’єднання за рахунок територій колишніх Росії та Австро-Угорщини.

Проте під час розпаду імперій національні держави зіткнулися з новим викликом - більшовизмом, який намагався підмінити націю класом, перетворити національні держави на радянські республіки, а у майбутньому - на єдину світову радянську республіку. Більшовикам 
вдалося захопити владу в Росії та Угорщині, тобто в метрополіях колишній імперій. Деякі національні держави Центральної та Східної Європи стали об'єктами більшовицької агресії, проте їхні військові і політичні лідери, що сповідували монархічні погляди, намагались відновити монархію в колишніх метрополіях, але на умовах збереження незалежності та територіальної цілості своїх держав (барон Карл Густав Еміль Маннергейм в Фінляндії, Павло Скоропадський в Україні, Петро Краснов на Дону, Йоганн Лайдонер в Естонії, та ін.).

Під монархічною контрреволюцією ми розуміємо контрреволюційну течію, метою якої було відновлення монархії на умовах збереження незалежності та територіальної цілості своїх держав. Монархічна контрреволюція взаємодіяла з сусідніми монархічними державами, а саме: російська з Німеччиною, угорська з Румунією. Російська монархічна контрреволюція сформувалася під час Брест-Литовської системи, через допомогу з боку Німеччини. Російська республіканська контрреволюція, навпаки, орієнтувалася на Антанту, тому перемога Антанти та поразка Німеччини означали занепад російської монархічної контрреволюції. Угорська монархічна контрреволюція вимушена була взаємодіяти з Румунією, тому перемога ії пов'язана 3 Версальською системою та Тріанонською угодою.

Аналіз досліджень. Спеціальних досліджень зв’язку Версальського мирного урегулювання та монархічної контрреволюції на територіях колишніх Російської та Австро-Угорської імперій поки що не проведено. Проте існує досить чисельна історіографія російської монархічної контрреволюції, у тому числі в контексті Брест-Литовської системи міжнародних відносин. Перші дослідження з цієї теми були проведені російськими емігрантами: генералом М. Головіним (Головин, 2011), полковником А. Зайцовим (Зайцов, 2006) та П. Мілюковим (Милюков, 1927). П. Милюков і А. Зайцов запропонували власні періодизації та підкреслили зв’язок між поразкою Німеччини в Першій світовій війні і занепадом російської монархічної контрреволюції.

А. Зайцов визначив такі головні етапи російської контрреволюції (Зайцов, 2006: 28):

1. Боротьба до австро-німецької інтервенції (жовтневий переворот 7 листопада 1917 - 18 лютого 1918 рр.);

2. Австро-німецька інтервенція (лютий - травень 1918 р.);

3. Формування контрреволюції (травень - вересень 1918 р.);

4. Осінь 1918 року (закінчення Першої світової війни 11 листопада).

11 листопада 1918 р. А. Зайцов називає «траурним днем російської контрреволюції», оскільки «День перемир'я не став початком світової боротьби з більшовизмом» (Зайцов, 2006: $333-$ 334). П. Мілюков також звернув увагу, що до поразки Німеччини 11 листопада 1918 р. все ще існувала можливість перемогти більшовизм в Росії, проте саме перемога Антанти цю можливість заблокувала (Милюков, 1927: 16, 75).

Е. фон Валь зробив важливий висновок, що більшовиків можуть зломити тільки національні сили, а головною причиною поразки білих республіканців в Росії було гасло «Є диної і неділимої» та небажання визнавати нові держави, що утворилися на території колишньої імперії. Це призвело до конфліктів між російськими та національними білими силами і забезпечило перемогу червоних, оскільки $3 / 4$ сил російських білих затрачувалися у боротьбі з національними державами та рухами (фон Валь, 1937: 8-12, 52, 56).

У світовій історичної науці поширена думку, що саме нові держави: Фінляндія, Україна і Дон 1918 року були базами всеросійської контрреволюції та могли провести реставрацію монархії в Росії (Головин, 2011; фон Валь, 1937: 53-56; Ахтамзян, 1963: 99-100, 125, 139, 159; Footman, 1961: 46; Kirby, 1979: 56).

У радянській історичній науці питання монархічної контрреволюції та нових держав на території колишньої Російської імперії розглянуто в працях Г. Иоффе (Иоффе, 1977), В. Зіміної (Зимина, 1989), причому останньою було введено поняття «германофільська контрреволюція», тобто чітко підкреслювався зв'язок російських монархістів і Німеччини. Серед сучасних досліджень контрреволюції на Дону та в Україні слід особливо виділити праці А. Вєнкова (Венков, 2008), Ю. Гражданова (Гражданов, 1997; Гражданов, Зимина, 1997), В. Федюка (Федюк, 1996), П. Кенеза (Kenez, 1971), А. Буравченкова (Буравченков, 2008). 
Дослідження монархічної контрреволюції в Фінляндії та Угорщині мають свою специфіку: по-перше, це головним чином дослідження політичних персон регентів: генерала барона Карла Густава Маннергейма (Клинге, 2004; Мери, 1997; Clements, 2009; Zaloga, 2015) і адмірала Miклоша Горті (Асташин, 2009) та румунського короля Фердинанда I (Ерещенко, 2009); по-друге, дослідження Визвольної війни в Фінляндії 1918 року (фон Валь, 1936; Upton, 1980; Jussila, Hentila, Nevakivi, 1995: 101-125; Jutikkala, Pirinen, 1974: 215-227; Kirby, 1979: 48-62; Puntila, 1975: 102-114; Эйде, 1931; Петров, 1961; Сюкияйнен, 1962; Холодовский, 1967) та Угорсько-румунської війни 1919 року (Kiriţescu, 1923; Bujac, 1933; Pastor, 1976; Bernad, Kliment, 2015: 3234; Preda, Prodan, 2012: 145-168; Torrey, 2011: 320-327). Крім того, досить важливою темою $є$ біографії громадських політичних лідерів-монархістів: Фінляндії - Пера Евінда Свинхувуда (Хяйкие, 2004), Угорщини - Пала Телекі (Пушкаш, 2009), Румунії - Іонела Бретіану (Виноградов, 2009; Hitchins, 2011).

Крім того, у нашому випадку слід звернути увагу на історіографію Версальського мирного договору. Так, наприклад, серед сучасних досліджень зацікавлення викликають роботи Д. Андельмана (Andelman, 2014), М. Макмилан (Macmillan, 2003). Розпад Австро-Угорщини та наслідки Тріанонської мирної угоди для взаємовідносин королівств Угорщини та Румунії розглянуто в праці О. Стикаліна (Стыкалин, 2014).

Мета статті - провести порівняльний аналіз розвитку монархічної контрреволюції Центральної та Східної Свропи: на території колишніх Російської та Австро-Угорської імперій у контексті зміни системи міжнародних відносин з Брест-Литовської на Версальську.

Виклад основного матеріалу. Монархічна контрреволюція у нових державах Центральної та Східної Європи, незалежно від форми правління, виникла під час антибільшовицьких Визвольних війн у колишній Російській імперії та Війни між Угорщиною і Румунією 1919 р. Чинниками виникнення монархічної контрреволюції були такі:

- монархічні традиції державності (Фінляндія, Угорщина);

- $\quad$ наявність харизматичних військових та політичних лідерів-монархістів у нових державах (Фінляндія - барон Карл Густав Еміль Маннергейм, Україна;

- $\quad$ гетьман Павло Скоропадський, Дон - отаман Петро Краснов, Естонія - Йоганн Лайдонер, Угорщина - Міклош Горті);

- підтримка з боку інших монархічних держав регіону (Німеччина - у випадку колишньої території Російської імперії та Румунія в випадку Угорщини).

Проте Німеччині не вдалося реставрувати монархію в Росії, натомість реставрація монархії в Угорщині відбулася саме через перемогу румунського війська над угорською червоною армією, оскільки угорські білі війська були дуже слабкими і нечисленними і формувалися за підтримкою румунської королівської армії (Bernad, Kliment, 2015: 32, 34; Preda, Prodan, 2012 : $148,156-157)$.

Монархічну контрреволюцію у нових державах, що виникли на території колишніх Російської та Австро-Угорської імперій, можна класифікувати за трьома типами. Перший - класичний династичний роялізм: відновлення колишньої династії. У Росії лідерами цього типу контрреволюції були генерали М. Юденич, С. Міллер, герцог Г. Лейхтенбергський, князь А. Лівен, П. Бермонд-Авалов. Другий - класичний національний роялізм, що поєднував у собі лояльність нації та новому престолу, тобто відновлення національної монархії шляхом обрання нової династії. Представниками цього типу були: адмірал М. Горті в Угорщині та голова Сенату Фінляндії П. Е. Свінгувуд. Третій - умовно кажучи «експорт-монархізм», прагнення керівництва нових, навіть республіканських, держав до повалення більшовизму та відновлення монархії у Росії задля збереження незалежності та територіальної цілості власної держави: у Фінляндії - генерал барон К. Г. Е. Маннергейм, в Україні - гетьман генерал П. Скоропадський, на Дону - отаман генерал П. Краснов, в Естонії - підполковник Й. Лайдонер. Отже, представники цього типу контрреволюції пов'язували легітимацію незалежності своєї країни з реставрацією монархії в Росії. Таким чином, деякі нові держави, незалежно від форми правління (Королівство Фінляндія, Українська Держава, Всевелике Військо Донське, Естонська республіка) стали базами монархічної контрреволюції. За словами Карла Густава Маннергейма, «така послуга» 
як реставрація, мала бути гідно оцінена й стати запорукою майбутніх дружних відносин (Маннергейм, 1999: 177). Проте ми маємо протилежний приклад, коли реставрація в Угорщині, що відбулася за допомогою румунського війська, не стала запорукою дружніх відносин між Угорщиною та Румунією через територіальні суперечки.

Перемога контрреволюції та одночасно національне визволення у Фінляндії та на Дону відбулося власними силами. В Україні та Угорщині контрреволюцію було принесено інтервентами: Німеччиною та Австро-Угорщиною в Україну, Румунією в Угорщину. Якщо в Фінляндії та Угорщині було відновлено монархію, як форму правління, то в Україні та на Дону зберігався республіканський лад через історичну традицію, хоча відбулася реставрація дореволюційного законодавства.

Головні етапи монархічної контрреволюції в означених країнах відбувалися по-різному. В Фінляндії це було відновлення дії Шведської Конституції 1772 р. 9 серпня 1918 р. та вже 18 серпня 1918 р. Сейм оголосив Велике князівство Фінляндське Королівством; 9 жовтня 1918 р. Сеймом було обрано королем Фридриха-Карла Гессен-Кассельського, який через поразку Німеччини та тиск з боку країн Антанти відрікся від корони 12 грудня 1918 р., регентом Королівства було призначено генерала барона Карла Густава Еміля фон Маннергейма (Ахтамзян, 1963: 101; Маннергейм, 1999: 142-143, 145-147, 151; Jussila, Hentila, Nevakivi, 1995: 124-125; Puntila, 1975: 112-113). В Україні відбувся гетьманський переворот за участю Німеччини та обрання Гетьманом Української Держави генерала Павла Скоропадського з'їздом хліборобів 29 квітня 1918 р. На Дону - обрання Кругом Отаманом генерала Петра Краснова 16 травня 1918 р. та проголошення незалежності Всевеликого Війська Донського 18 травня 1918 р. (Краснов, 1991: 191-198; Footman, 1961: 74-75). В Угорщині - проголошення Національними Зборами адмірала М. Горті регентом Королівства 1 березня 1920 р. (Horthy, 2000: 130-131). Король Угорщини Карой IV офіційно не відрікався від корони, але його намагання повернути престол у Будапешті зустріли рішучий дипломатичний опір з боку країн Антанти (Асташин, 2009: 376; Пушкаш, 2009: 399). Саме чинник Антанти змусив два королівства (Фінляндію і Угорщину) існувати без короля.

Хронологічно монархічну контрреволюцію в Центральній та Східній Європі можна умовно розділити на два головні періоди. Перший - Брест-Литовська система на території колишньої Російської імперії. Другий - складання Версальської системи на території колишніх Російської та Австро-Угорської системи. Як можна помітити, ці дві системи були абсолютно протилежними. Брест-Литовська була біполярною, тобто існували два центри сили: Німеччина та радянська Росія. Ідеологічно це можна представити у вигляді: монархізм проти більшовизму. Німеччина розповсюдила свої династії на Литву та Фінляндію, розробляла плани реставрації в Росії. Більшовики Росії, навпаки, намагались експортувати свій режим у Європу, особливо в Центральну та Східну Свропу. Брест-Литовська система існувала завдяки балансу сил Німеччини і радянської Росії: Німеччина не могла відновити монархію в Росії, але й більшовики не могли розповсюджувати радянську владу в Європі. Поразка Німеччини у Першій світовій війні та початок формування Версальської системи порушив баланс сил, що призвело до існування королівства без короля в Фінляндії, захоплення більшовиками та ліквідації державності України і Дону; розповсюдження більшовизму в Центральну Європу (Macmillan, 2003: 66, 128, 158; Виноградов, 2009: 218), зокрема створення Угорської радянської республіки. Замість реальної боротьби з більшовизмом Версальська система максимум на що спромоглася, то тільки на створення Санітарного кордону. Шанс ліквідувати більшовизм в Росії вже було упущено.

Таким чином, кульмінацією монархічної контрреволюції в Росії було створення Брест-Литовської системи міжнародних відносин. Початком монархічної контрреволюції в Східній Європі може слугувати дата 26-27 січня 1918 р., тобто початок війни між РСФРР та Королівством Румунія і Визвольної війни у Фінляндії. Кінцевими датами в масштабах всієї Центральної та Східної Європи монархічної контрреволюції слід вважати підписання Тріанонської мирної угоди 4 червня 1920 р., яка закріпила кордони та міжнародне визнання Королівства Угорщини, i Тартуської мирної угоди 14 жовтня 1920 р., що поставила крапку у війні між РСФРР та Фінляндією, тобто, фактично, завершення післявоєнного мирного урегулювання в Свропі. Або можна 
запропонувати інші хронологічні рамки монархічної контрреволюції Центральної та Східної Європи: 26 січня 1918 - 1 березня 1920 р., тобто від нападу радянської Росії на Королівство Румунія та Велике князівство Фінляндія до проголошення адмірала М. Горті регентом Королівства Угорщина. Всередині періоду слід особливо виділити два етапи: перший - від початку німецької та австро-угорської інтервенції в Східній Європі до Комп'єнського перемир'я (18 лютого - 11 листопада 1918 р.) - існування Брест-Литовської системи, оскільки поразка Німеччини призвела до падіння Гетьманату в Україні та втрати державності України та Дону; та другий - вже під час складання Версальської системи - Угорсько-румунська війна (16 квітня - 6 серпня 1919 р.), тому що поразка червоних у цій війні призвела до реставрації монархії в Угорщині.

Зміна систем міжнародних відносин у Центральній та Східній Європі з Брест-Литовської на Версальську призвела, з одного боку, до ліквідації державності України та Дону, втрати значної території Королівства Угорщина, але, з іншого боку, до завершення національного об'єднання Королівства Румунії (Ерещенко, 2009: 180). Тут треба зазначити, що король Румунії Фердинанд I не ратифікував Бухарестську мирну угоду від 7 травня 1918 р., що, формально, зберігало стан тимчасового перемир'я, але не миру з Центральними державами, та дозволило румунському війську розпочати бойові дії на завершальному етапі війни й опинитися серед переможців (Hitchins, 2011: 111; Macmillan, 2003: 131; Ерещенко, 2009: 191). Водночас для Угорщини жорсткі умови Тріанонського миру були продиктовані спротивом країн-переможців проти посилення ролі Угорщини в регіоні як правонаступниці імперії Габсбургів та потенційльного союзника Німеччини (Стыкалин, 2014: 79). Україна і Дон взагалі розглядалися Антантою як сателіти Німеччини, так само спочатку і Фінляндія. Проте, ще до поразки Німеччини барон Карл Густав Еміль Маннергейм доклав неймовірних дипломатичних зусиль, щоб докорінно змінити ставлення до Фінляндії країн Антанти, отримати від них визнання та встановити дипломатичні відносини (Маннергейм, 1999: 138, 140, 142-154, 166). На відмінну від України, Фінляндія мала можливість вести самостійну зовнішньою політику та більше можливостей для дипломатичних маневрів. Військовий потенціал Фінляндії дозволив їй не тільки успішно захищатися від російських більшовиків, але й взяти участь у визволенні Естонії, стати регіональним центром сили на Балтиці (Маннергейм, 1999: 148, 156-157). Фінляндія спільно з Естонією цілком могли зайняти Петроград та відновити монархію в Росії (Маннергейм, 1999: 177-178; Нелидов, 1929: 103, 105-106; Петров, 1961: 21-23, 30-31), як це зробила Румунія в Угорщині, проте саме небажання уряду адмірала О. Колчака визнати незалежність нових країн не дозволила це зробити (Маннергейм, 1999: 139, 142, 180-181; Нелидов, 1929: 87, 93, 97-98, 100; Эйде, 1931: 30; Петров, 1961: 36). Натомість, в Угорщині вдалося перемогти більшовизм та провести реставрацію, у тому числі завдяки реалістичній політиці адмірала М. Горті, який вимушений був підписати Тріанонську мирну угоду, яка зафіксувала значні територіальні втрати країни.

Оскільки Німеччина не наважилась на військові операції проти радянської Росії навіть після вбивства в Москві свого посла графа Вільгельма фон Мірбах-Харфа, тобто casus belli, то скинути більшовицьку диктатуру в Росії могли нові незалежні держави: Королівство Фінляндія, Всевелике Військо Донське та Українська Держава, але для цього не вистачило часу через поразку Німеччини.

В умовах складання Версальської системи міжнародних відносин перемогти більшовизм в Росії виявилося неможливим, у тому числі через суперечності серед Союзників (Великої 4-ки), тому залишалось тільки зупинити його просування в Європу, створивши «Санітарний кордон». На флангах «Санітарного кордону» сформувалися два регіональні центри сили: Фінляндія стала щитом Скандинавії та Балтії, Румунія - щитом Балкан (Hitchins, 2011: 119, 121; Macmillan, 2003: 128; Виноградов, 2009: 218). Причому Румунія вимушена була вести війну з більшовизмом на два фронти: Російський та Угорський (Andelman, 2014: 244; Macmillan, 2003: 128; Виноградов, 2009: 218).

Висновки. Таким чином, порівняльний аналіз Брест-Литовської та Версальської систем міжнародних відносин у контексті монархічної контрреволюції Центральної та Східної Свропи дає підставу для таких висновків. 
По-перше, Німеччина намагалася, з одного боку, розчленувати європейську частину Російської імперії, створити пояс буферних держав, який відділяв би її від Росії, та поставити на престоли в нових державах представників німецьких династій, але, з іншого, Німеччина планувала скинути більшовицький уряд та реставрувати монархію у Росії. Проте, для цього у Німеччини не вистачало сил через продовження війни на Західному, Італійському, Балканському, Близькосхідному фронтах, та розміщення додаткових контингентів в Румунії, Україні і Балтійському регіоні. Зі свого боку, більшовицький уряд Росії намагався розповсюдити радянську владу в Центральній та Східній Європі, але не наважувався на відкритий збройний конфлікт з Німеччиною теж через нестачу сил, оскільки головні сили більшовиків були задіяні на Донському та Сибірському фронтах. Отже, Брест-Литовська система була біполярною через два центри сили: Німеччину та радянську Росію. Протистояння мало ідеологічний характер: монархізм проти більшовизму.

По-друге, поразка Німеччини та розпад Австро-Угорщини створили певний хаос та вакуум сили в Центральній та Східній Свропі, чим неодмінно скористалися більшовики, ліквідували дві держави (Україну і Дон) та встановив радянську владу в Угорщині. Значною мірою цьому сприяла недальновидна політика Союзників, які розглядали Україну і Дон як сателітів Німеччини та зробили ставку на «Єдину та неподільну Росію».

По-трете, успіх реставрації залежав, у тому числі, від здатності білих урядів до компромісу в територіальних та питанні визнання нових держав, що утворилися на територіях колишніх імперій. Випадки Росії та Угорщини підтверджують цю тезу.

По-четверте, обидві системи міжнародних відносин передбачали розчленування території переможених імперій та визнання нових незалежних держав. Різниця полягала у тому, що Брест-Литовська стосувалася Росії, а Версальська - Австро-Угорщини. Крім того, Німеччина в рамках Брест-Литовської системи робила ставку на монархізм, Велика трійка (США, Франція, Велика Британія) у рамках Версальської системи, навпаки, перешкоджала розповсюдженню монархій, вимагала республіканського устрою нових держав.

По-п’яте, головна різниця між системами міжнародних відносин полягала у кількості полюсів. Якщо Брест-Литовська система була біполярною: Німеччина vs радянська Росія, то Версальська система - багатополярною, оскільки Німеччину замінили «Велика Трійка» (США, Франція, Велика Британія) та «Велика Четвірка» (США, Франція, Велика Британія, Італія), всередині яких існували свої суперечності, що значно ускладнювало боротьбу з більшовизмом.

Крім того, якщо стабільність Брест-Литовської системи залежала винятково від дій та рішень головних гравців (Росії та Німеччини), то в Версальській системі сформувалися регіональні центри сили, які почали відігравати більш важливу та самостійну роль, зокрема Фінляндія і Румунія, що розміщувалися на флангах «Санітарного кордону».

\section{СПИСОК ВИКОРИСТАНИХ ДЖЕРЕЛ І ЛІТЕРАТУРИ}

Асташин, 2009 - Асташин Н. Миклош Хорти - адмирал в своем лабиринте // До и после Версаля. Политические лидеры и идея национального государства в Центральной и Юго-Восточной Европе. Москва, 2009. C. 374-393.

Ахтамзян, 1963 - Ахтамзян А. От Бреста до Киля. Провал антисоветской политики германского империализма в 1918 году. Москва: Из-во ИМО, 1963. 220 с.

Буравченков, 2008 - Буравченков А. Гетьман П. Скоропадський і Білий рух (суб'єктивний погляд) // Гетьманат Павла Скоропадського: історія, постаті, контраверсії. Київ: Видавництво ім. Олени Теліги, 2008. C. $74-84$.

фон Валь, 1936 - Валь Э. фон. Война белых и красных в Финляндии в 1918 году. Таллинн, 1936. 94 с.

фон Валь, 1937 - Валь Э. фон. Значение и роль Украины в вопросе освобождения России от большевиков на основании опыта 1918 - 1920 гг. Таллинн, 1937. 72 с.

Венков, 2008 - Венков А. Атаман Краснов и Донская армия. 1918 год. Москва: Вече, 2008. 500 с.

Виноградов, 2009 - Виноградов В. Румынский сфинкс Ионел Братиану // До и после Версаля. Политические лидеры и идея национального государства в Центральной и Юго-Восточной Европе. Москва, 2009. C. $195-220$.

Головин, 2011 - Головин Н. Российская контрреволюция в 1917 - 1918 гг. В 2-х т. Т. 2. Москва: Айрис-пресс, 2011. 704 с. 
Гражданов, 1997 - Гражданов Ю. Всевеликое Войско Донское в 1918 году. Волгоград: ВАГС, 1997. $156 \mathrm{c}$.

Гражданов, Зимина, 1997 - Гражданов Ю., Зимина В. Союз орлов: Белое дело России и германская интервенция в 1917 - 1918 гг. Волгоград: ВАГС, 1997. 280 с.

Ерещенко, 2009 - Ерещенко М. Король Фердинанд I - объединитель румынских земель // До и после Версаля. Политические лидеры и идея национального государства в Центральной и Юго-Восточной Европе. Москва, 2009. С. 180-194.

Зайцов, 2006 - Зайцов А. 1918: очерки истории Русской Гражданской войны. Москва: Кучково поле, 2006. $368 \mathrm{c}$.

Зимина, 1989 - Зимина В. Крах германофильской монархической контрреволюции на Юге России в годы Гражданской войны и интервенции. Калинин, 1989. 88 с.

Иоффе, 1977 - Иоффе Г. Крах российской монархической контрреволюции. Москва, 1977. 320 с.

Клинге, 2004 - Клинге М. Густав Маннергейм (1867-1951). Президент Республики, Регент, Маршал Финляндии // Сто замечательных финнов. Калейдоскоп биографий. Хельсинки, 2004. С. 364-379.

Краснов, 1991 - Краснов П. Всевеликое Войско Донское // Архив Русской революции: В 22 т. Т. 5. Москва: Терра: Политиздат, 1991. С. 190-321.

Маннергейм, 1999 - Маннергейм К. Г. Мемуары. Москва: Вагриус, 1999. 510 с.

Мери, 1997 - Мери В. Карл Густав Маннергейм - Маршал Финляндии. Москва: Новое литературное обозрение, 1997. $208 \mathrm{c.}$

Милюков, 1927 - Милюков П. Россия на переломе: большевистский период Русской революции. В 2-х т. Т. ІІ.: Антибольшевистское движение. Париж, 1927. IX, 281 с.

Нелидов, 1929 - Колчак и Финляндия / вступ. ст. Н. Нелидова // Красный Архив. 1929. Т. 2 (33). C. $82-144$.

Петров, 1961 - Петров В. Финляндия в планах империалистических держав в 1918-1920 годах. Петрозаводск: Госиздат. КАССР, 1961.74 с.

Пушкаш, 2009 - Пушкаш А. Политический и государственный деятель Венгрии Пал Телеки // До и после Версаля. Политические лидеры и идея национального государства в Центральной и Юго-Восточной Европе. Москва, 2009. С. 394-428.

Стыкалин, 2014 - Стыкалин А. Последствия поражения Австро-Венгрии в Первой Мировой войне и Трианонского мирного договора 1920 г. для отношений Венгрии с Румынией в условиях Версальской системы международных отношений // Вестник Вятского государственного гуманитарного университета. 2014. № 6. С. $78-83$.

Сюкияйнен, 1962 - Сюкияйнен И. Революционные события 1917-1918 гг. в Финляндии. Петрозаводск: Карельское книгоиздательство, 1962. 312 с.

Федюк, 1996 - Федюк В. Белые: антибольшевистское движение на Юге России. 1917-1918 гг. Москва: АИРО-ХХ, 1996. 153 с.

Холодовский, 1967 - Холодовский В. Революция 1918 года в Финляндии и германская интервенция. Москва: Наука, 1967. 388 с.

Хяйкие, 2004 - Хяйкие М. Пер Эвинд Свинхувуд (1861 - 1944). Президент Республики, Регент // Сто замечательных финнов. Калейдоскоп биографий. Хельсинки, 2004. С. 535-546.

Эйде, 1931 - Эйде И. Финляндия и ее внешняя политика. Москва; Ленинград: Молодая гвардия, 1931. 95 c.

Andelman, 2014 - Andelman D. A Shattered Peace. Versailles 1919 and the Price We Pay Today. New York: John Wiley \& Son, Inc., 2014. 362 p.

Bernad, Kliment, 2015 - Bernad D., Kliment Ch. Magyar Warriors. The History of the Royal Hungarian Armed Forces, 1919 - 1945. Vol. I. Solihull: Helion \& Co. Ltd., 2015. 404 p.

Bujac, 1933 - Bujac J. Campagnes de l'armée roumaine, 1916 - 1919. Paris: Charles-Lavauzelle \& Cie,1933. $254 \mathrm{p}$.

Clements, 2009 - Clements J. Mannerheim. President, Soldier, Spy. London: Haus Pub., 2009. 336 p.

Footman, 1961 - Footman D. Civil War in Russia. New York, 1961. 328 p.

Hitchins, 2011 - Hitchins K. Ionel Bratianu. Romania (Makers of the Modern World), London, Haus Publishing Ltd, 2011.

Horthy, 2000 - Horthy N. Memoirs. Safety Harbor: Simon Publications, 2000. 348 p.

Jussila, Hentila, Nevakivi, 1995 - Jussila O., Hentila S., Nevakivi J. From Grand Duchy to A Modern State. A Political History of Finland Since 1809. London: Hurst and Co., 1995. 384 p.

Jutikkala, Pirinen, 1974 - Jutikkala E., Pirinen K. History of Finland. London: Heinemann Ltd., 1974. 256 p. 
Kenez, 1971 - Kenez P. Civil War in South Russia, 1918. The First Year of the Volunteer Army. Berkeley; Los-Angeles; London: California University Press, 1971. 351 p.

Kirby, 1979 - Kirby D. Finland in the Twentieth Century. London: Hurst and Co., 1979. 253 p.

Kirițescu, 1923 - Kirițescu C. Istoria Războiului pentru întregirea României, 1916 - 1919. Volumul Al II. București: Editura Casei Școalelor, Tipografia România Nouă, 1923. 668 p.

Macmillan, 2003 - Macmillan M. Paris 1919. Six Months that Changed the World. New York: Random House, 2003. 570 p.

Pastor, 1976 - Pastor P. Hungary between Wilson and Lenin: the Hungarian Revolution of 1918-1919 and the Big Three. Ann Arbor: East European Quarterly, 1976. 191 p.

Preda, Prodan, 2012 - Preda D., Prodan C. Romania in WWI. A Concise History. Saarbrücken: Lambert Academic Publishing, 2012. 187 p.

Puntila, 1975 - Puntila L. The Political History of Finland 1809-1966. London: Heinemann Ltd, 1975. 248 p.

Torrey, 2011 - Torrey G. The Romanian Battlefront in World War I. Lawrence: The University Press of Kansas, 2011. $422 \mathrm{p}$.

Upton, 1980 - Upton A. The Finnish Revolution: 1917-1918. Minneapolis: University of Minnesota Press, 1980. 608 p.

Zaloga, 2015 - Zaloga S. Gustaf Mannerheim. Leadership. Strategy. Conflict. Oxford; New York: Osprey Publishing Ltd., 2015. 64 p.

\section{REFERENCES}

Astashin, 2009 - Astashin N. Miklosh Khorti - admiral v svoem labirinte [Miklos Horthy - admiral in his labyrinth] // Do i posle Versalya. Politicheskie lidery i ideya natsionalnogo gosudarstva v Tsentralnoy i Yugo-Vostochnoy Evrope [Before and After Versailles: Political Leaders and the nation-state idea in Central and Southern-Eastern Europe]. Moskva, 2009. S. 374-393. [in Russian].

Akhtamzyan, 1963 - Akhtamzyan A. Ot Bresta do Kilya. Proval antisovetskoy politiki germanskogo imperializma v 1918 godu [From Brest to Kiel: Failure of Anti-Soviet Politics of German Imperialism in 1918]. Moskva: Iz-vo IMO, 1963. 220 s. [in Russian].

Buravchenkov, 2008 - Buravchenkov A. Hetman P. Skoropadskyi i Bilyi rukh (subiektyvnyi pohliad) [Hetman P. Skoropadsky and the White Movement (subjective view)] // Hetmanat Pavla Skoropadskoho: istoriia, postati, kontraversii [Pavel Skoropadsky's Hetman Statehood: History, Figures, Counter-versions]. Kyiv: Vydavnytstvo im. Oleny Telihy, 2008. S. 74-84. [in Ukrainian].

fon Val, 1936 - Val E. fon Voyna belykh i krasnykh v Finlyandii v 1918 godu [E. von Val The War of Whites and Reds in Finland in 1918]. Tallinn, 1936. 94 s. [in Russian].

fon Val, 1937 - Val E. fon Znachenie i rol Ukrainy v voprose osvobozhdeniya Rossii ot bolshevikov na osnovanii opyta 1918-1920 gg. [E. von Val The Role of Ukraine in the Question of Liberation of Russia from the Bolsheviks on the Base of theExperience 1918 - 1920] Tallinn, 1937. 72 s. [in Russian].

Venkov, 2008 - Venkov A. Ataman Krasnov i Donskaya armiya. 1918 god [Ataman Krasnov and Don Army, 1918]. Moskva: Veche, 2008. 500 s. [in Russian].

Vinogradov, 2009 - Vinogradov V. Rumynskiy sfinks Ionel Bratianu [Romanian Sphinx - Ionel Bratianu] // Do i posle Versalya. Politicheskie lidery i ideya natsionalnogo gosudarstva v Tsentralnoy i Yugo-Vostochnoy Evrope [Before and After Versailles: Political Leaders and the nation-state idea in Central and Southern-Eastern Europe]. Moskva, 2009. S. 195-220. [in Russian].

Golovin, 2011 - Golovin N. Rossiyskaya kontrrevolyutsiya v 1917 - 1918 gg. [Russian Counter-revolution in 1917-1918] V 2-kh t. T. 2. Moskva: Ayris-press, 2011. 704 s. [in Russian]

Grazhdanov, 1997 - Grazhdanov Yu. Vsevelikoe Voysko Donskoe v 1918 godu [Almighty Don Host in 1918]. Volgograd: VAGS, 1997. 156 s. [in Russian].

Grazhdanov, Zimina, 1997 - Grazhdanov Yu., Zimina V. Soyuz orlov: Beloe delo Rossii i germanskaya interventsiya v 1917-1918 gg. [The Union of Eagles: The White Cause of Russia and German Intervention in 1917 - 1918] Volgograd: VAGS, 1997. 280 s. [in Russian].

Yereshchenko, 2009 - Yereshchenko M. Korol Ferdinand I - obedinitel rumynskikh zemel [King Ferdinand I -Romanian Land Unifier] // Do i posle Versalya. Politicheskie lidery i ideya natsionalnogo gosudarstva v Tsentralnoy i Yugo-Vostochnoy Evrope [Before and After Versailles: Political Leaders and the nation-state idea in Central and Southern-Eastern Europe]. Moskva, 2009. S. 180-194. [in Russian].

Zaytsov, 2006 - Zaytsov A. 1918: ocherki istorii Russkoy Grazhdanskoy voyny [1918: Essays on History of Russian Civil War]. Moskva: Kuchkovo pole, 2006. 368 s. [in Russian]. 
Zimina, 1989 - Zimina V. Krakh germanofilskoy monarkhicheskoy kontrrevolyutsii na Yuge Rossii v gody Grazhdanskoy voyny i interventsii [The Collapse of Germanophiles Monarchist Counter-revolution in South of Russia in Years of Civil War and Intervention]. Kalinin, 1989. 88 s. [in Russian].

Ioffe, 1977 - Ioffe G. Krakh rossiyskoy monarkhicheskoy kontrrevolyutsii [The Collapse of Russian Monarchist Counter-revolution]. Moskva, 1977. 320 s. [in Russian].

Klinge, 2004 - Klinge M. Gustav Mannergeym (1867 - 1951). Prezident Respubliki, Regent, Marshal Finlyandii [Gustav Mannerheim (1867-1951): President of Republic, Regent, Marshal of Finland] // Sto zamechatelnykh finnov. Kaleydoskop biografiy [Hundred of Brilliant Finns: Kaleidoscope of Biographies]. Khelsinki [Helsinki], 2004. S. 364-379. [in Russian].

Krasnov, 1991 - Krasnov P. Vsevelikoe Voysko Donskoe [Almighty Don Host] // Arkhiv Russkoy revolyutsii [Archieve of Russian Revolution]: V 22 t. T. 5. Moskva: Terra: Politizdat, 1991. S. 190-321. [in Russian].

Mannergeym, 1999 - Mannergeym K. G. Memuary [Mannerheim Karl Gustav Memoirs]. Moskva: Vagrius, 1999. 510 s. [in Russian].

Meri, 1997 - Meri V. Karl Gustav Mannergeym - Marshal Finlyandii [Karl Gustav Mannerheim - Marshal of Finland]. Moskva: Novoe literaturnoe obozrenie, 1997. 208 s. [in Russian].

Milyukov, 1927 - Milyukov P. Rossiya na perelome: bolshevistskiy period Russkoy revolyutsii [Russia in a Crossroads: the Bolshevik's Period of Russian Revolution]. V 2-kh t. T. II.: Antibolshevistskoe dvizhenie [Anti-Bolsheviks Movement]. Parizh [Paris], 1927. IX, 281 s. [in Russian].

Nelidov, 1929 - Kolchak i Finlyandiya / vstup. st. N. Nelidova [Kolchak and Finland] // Krasnyy Arkhiv [Red Archieve]. 1929. T. 2(33). S. 82-144. [in Russian].

Petrov, 1961 - Petrov V. Finlyandiya v planakh imperialisticheskikh derzhav v 1918 - 1920 godakh [Finland in the Plans of Imperialist Powers in 1918 - 1920]. Petrozavodsk: Gosizdat. KASSR, 1961. 74 s. [in Russian].

Pushkash, 2009 - Pushkash A. Politicheskiy i gosudarstvennyy deyatel Vengrii Pal Teleki [Puskas A. Pal Teleki as a Politician and Statesman of Hungary] // Do i posle Versalya. Politicheskie lidery i ideya natsionalnogo gosudarstva v Tsentralnoy i Yugo-Vostochnoy Evrope [Before and After Versailles: Political Leaders and the nation-state idea in Central and Southern-Eastern Europe]. Moskva, 2009. S. 394-428. [in Russian].

Stykalin, 2014 - Stykalin A. Posledstviya porazheniya Avstro-Vengrii v Pervoy Mirovoy voyne i Trianonskogo mirnogo dogovora 1920 g. dlya otnosheniy Vengrii s Rumyniey v usloviyakh Versalskoy sistemy mezhdunarodnykh otnosheniy [The Consequences of the Defeat of Austro-Hungary in World War I and Trianon Peace Treaty 1920 for the Interrelations between Hungary and Romania under the Conditions of Versailles System of International Relations] // Vestnik Vyatskogo gosudarstvennogo gumanitarnogo universiteta [Herald of Viatka State Humanitarian University]. 2014. № 6. S. 78-83. [in Russian].

Syukiyaynen, 1962 - Syukiyaynen I. Revolyutsionnye sobytiya 1917 - 1918 gg. v Finlyandii [Revolutionary Events of 1917-1918 in Finland]. Petrozavodsk: Karelskoe knigoizdatelstvo, 1962. 312 s. [in Russian].

Fedyuk, 1996 - Fedyuk V. Belye: antibolshevistskoe dvizhenie na Yuge Rossii. 1917 - 1918 gg. [The Whites: Anti-Bolshevik Movement in the South of Russia]. Moskva: AIRO-KhKh, 1996. 153 s. [in Russian].

Kholodovskiy, 1967 - Kholodovskiy V. Revolyutsiya 1918 goda v Finlyandii i germanskaya interventsiya [Revolution of 1918 in Finland and German Intervention]. Moskva: Nauka, 1967. 388 s. [in Russian].

Khyaykie, 2004 - Khyaykie M. Per Evind Svinkhuvud (1861 - 1944). Prezident Respubliki, Regent [Haikie M. Pehr Evind Svinhufvud (1861-1944) as a President of Republic, Regent] // Sto zamechatelnykh finnov. Kaleydoskop biografiy [Hundred of Brilliant Finns: Kaleidoscope of Biographies]. Khelsinki [Helsinki], 2004. S. 535-546. [in Russian].

Eyde, 1931 - Eyde I. Finlyandiya i ee vneshnyaya politika [Finland and Its Foreign Politics]. Moskva; Leningrad: Molodaya gvardiya, 1931. 95 s. [in Russian].

Andelman, 2014 - Andelman D. A Shattered Peace. Versailles 1919 and the Price We Pay Today. New York: John Wiley \& Son, Inc., 2014. 362 p. [in English].

Bernad, Kliment, 2015 - Bernad D., Kliment Ch. Magyar Warriors. The History of the Royal Hungarian Armed Forces, 1919-1945. Vol. I. Solihull: Helion \& Co. Ltd., 2015. 404 p. [in English].

Bujac, 1933 - Bujac J. Campagnes de l'armée roumaine, 1916 - 1919 [Campaigns of Romanian Army]. Paris: Charles-Lavauzelle \& Cie,1933. 254 p. [in French].

Clements, 2009 - Clements J. Mannerheim. President, Soldier, Spy. London: Haus Pub., 2009. 336 p.

Footman, 1961 - Footman D. Civil War in Russia. New York, 1961. 328 p. [in English].

Hitchins, 2011 - Hitchins K. Ionel Bratianu. Romania (Makers of the Modern World), London, Haus Publishing Ltd, 2011. [in English].

Horthy, 2000 - Horthy N. Memoirs. Safety Harbor: Simon Publications, 2000. 348 p. [in English].

Jussila, Hentila, Nevakivi, 1995 - Jussila O., Hentila S., Nevakivi J. From Grand Duchy to A Modern State. A Political History of Finland Since 1809. London: Hurst and Co., 1995. 384 p. [in English]. 
Jutikkala, Pirinen, 1974 - Jutikkala E., Pirinen K. History of Finland. London: Heinemann Ltd., 1974. 256 p. [in English].

Kenez, 1971 - Kenez P. Civil War in South Russia, 1918. The First Year of the Volunteer Army. Berkeley; Los-Angeles; London: California University Press, 1971. 351 p. [in English].

Kirby, 1979 - Kirby D. Finland in the Twentieth Century. London: Hurst and Co., 1979. 253 p. [in English].

Kirițescu, 1923 - Kirițescu C. Istoria Războiului pentru întregirea României, 1916-1919 [History of War for Integration of Romania]. Volumul Al II. București: Editura Casei Școalelor, Tipografia România Nouă, 1923. 668 p. [in Romanian].

Macmillan, 2003 - Macmillan M. Paris 1919. Six Months that Changed the World. New York: Random House, 2003. 570 p. [in English].

Pastor, 1976 - Pastor P. Hungary between Wilson and Lenin: the Hungarian Revolution of 1918 - 1919 and the Big Three. Ann Arbor: East European Quarterly, 1976. 191 p. [in English].

Preda, Prodan, 2012 - Preda D., Prodan C. Romania in WWI. A Concise History. Saarbrücken: Lambert Academic Publishing, 2012. 187 p. [in English].

Puntila, 1975 - Puntila L. The Political History of Finland 1809 - 1966. London: Heinemann Ltd, 1975. 248 p. [in English].

Torrey, 2011 - Torrey G. The Romanian Battlefront in World War I. Lawrence: The University Press of Kansas, 2011. 422 p. [in English].

Upton, 1980 - Upton A. The Finnish Revolution: 1917 - 1918. Minneapolis: University of Minnesota Press, 1980. 608 p. [in English].

Zaloga, 2015 - Zaloga S. Gustaf Mannerheim. Leadership. Strategy. Conflict. Oxford; New York: Osprey Publishing Ltd., 2015. 64 p. [in English].

Стаття надійшла до редакиії 10.02.2018 p. 